Ecology

\title{
Anoplurans (Insecta: Psocodea: Anoplura) associated with rodents distributed in the neotropical region of Mexico
}

\author{
Anopluros (Insecta: Psocodea: Anoplura) asociados con roedores en la región neotropical de México \\ Sokani Sánchez-Montes ${ }^{\mathrm{a}, \mathrm{b}}$, Carmen Guzmán-Cornejo ${ }^{\mathrm{a}, *}$, Fabiola Ramírez-Corona ${ }^{\mathrm{c}}$, \\ Livia León-Paniagua ${ }^{\mathrm{d}}$ \\ ${ }^{a}$ Laboratorio de Acarología, Departamento de Biología Comparada, Facultad de Ciencias, Universidad Nacional Autónoma de México, Avenida Universidad \\ 3000, Ciudad Universitaria, 04510 México, D.F., Mexico \\ ${ }^{\mathrm{b}}$ Laboratorio de Inmunoparasitología, Unidad de Investigación en Medicina Experimental, Facultad de Medicina, Universidad Nacional Autónoma de México, \\ Dr. Balmis 148, Col. Doctores , 06726 México, D.F., Mexico \\ ${ }^{\mathrm{c}}$ Taller de Sistemática y Biogeografía, Departamento de Biología Evolutiva, Facultad de Ciencias, Universidad Nacional Autónoma de México, \\ Avenida Universidad 3000, Ciudad Universitaria, 04510 México, D.F., Mexico \\ d Museo de Zoología, Departamento de Biología Evolutiva, Facultad de Ciencias, Universidad Nacional Autónoma de México, Avenida Universidad 30oo, \\ Ciudad Universitaria, 04510 México, D.F., Mexico
}

Received 16 June 2015; accepted 8 December 2015 Available online 7 May 2016

\begin{abstract}
From April to December of 2010, we performed a cross sectional study in order to collect and identify the species of anoplurans associated with cricetid and heteromyd rodents from montane forests in 5 localities in Guerrero and Oaxaca, Mexico. We analyzed 147 rodents belonging to 10 cricetid species and 1 heteromyd species. A total of 378 sucking lice were collected (189 $\%, 106 \sigma^{7}, 83$ nymphs), distributed in 6 species (Fahrenholzia microcephala, Hoplopleura emphereia, Hoplopleura ferrisi, Hoplopleura reithrodontomydis, Neohaematopinus neotomae, Polyplax auricularis) and 2 families (Hoplopleuridae and Polyplacidae). Lice specimens were processed for morphological and molecular identification, using the mitochondrial gene cytochrome oxidase subunit I. Infestations were characterized based on the prevalence and mean abundance. Five of the 6 species were confirmed by molecular analysis. The highest levels of infestation were recorded for H. emphereia $(66.7 \%$; 4.4) on Megadontomys thomasi. All localities represent new records for the species studied.

All Rights Reserved @ 2016 Universidad Nacional Autónoma de México, Instituto de Biología. This is an open access item distributed under the Creative Commons CC License BY-NC-ND 4.0.
\end{abstract}

Keywords: Sucking lice; Cythocrome oxidase subunit I; Rodents; Mexico

\section{Resumen}

De abril a diciembre de 2010 desarrollamos un estudio con el objetivo de recolectar e identificar anopluros asociados con roedores cricétidos y heterómidos de bosques montañosos en 5 localidades en Guerrero y Oaxaca, México. Analizamos un total de 147 roedores pertenecientes a 10 especies de cricétidos y una especie de heterómido. Se recolectó un total de 378 piojos (189 †, 106 ơ, 83 ninfas), distribuidos en 6 especies (Fahrenholzia microcephala, Hoplopleura emphereia, Hoplopleura ferrisi, Hoplopleura reithrodontomydis, Neohaematopinus neotomae, Polyplax auricularis) y 2 familias (Hoplopleuridae y Polyplacidae). Los piojos fueron procesados para su identificación morfológica y molecular, usando el gen mitocondrial citocromo oxidasa subunidad I. Las infestaciones fueron caracterizadas con base en la prevalencia y la abundancia promedio. Cinco de las 6 especies fueron confirmadas molecularmente. Los más altos niveles de infestación fueron alcanzados por H. emphereia (66.7\%; 4.4) sobre Megadontomys thomasi. Todas las localidades representan nuevos registros para las especies estudiadas.

Derechos Reservados (C) 2016 Universidad Nacional Autónoma de México, Instituto de Biología. Este es un artículo de acceso abierto distribuido bajo los términos de la Licencia Creative Commons CC BY-NC-ND 4.0.

Palabras clave: Piojos; Citocromo oxidasa subunidad I; Roedores; México

\footnotetext{
* Corresponding author.

Peer Review under the responsibility of Universidad Nacional Autónoma de México E-mail address: carguzmancornejo@ gmail.com (C. Guzmán-Cornejo).
} 


\section{Introduction}

Sucking lice are obligate hematophagous ectoparasites of eutherian mammals. Currently, 550 species of Anoplura distributed in 16 families and 49 genera have been recorded worldwide (Durden \& Musser, 1994; Light, Smith, Allen, Durden, \& Reed, 2010); two-thirds of these arthropods belong to the families Polyplacidae and Hoplopleuridae, both including species parasites of rodents (Durden, 2002). The inventory of Mexican sucking lice is conformed by 44 species distributed in 8 genera (Antarctophthirus Enderlein, 1906; Enderleinellus Fahrenholz, 1912; Fahrenholzia Kellogg and Ferris, 1919; Hoplopleura Enderlein, 1904; Linognathoides Cummings, 1914; Linognathus Enderlein, 1905; Neohaematopinus Mjöberg, 1910 and Polyplax Enderlein, 1904) and 5 families (Echinophthiriidae, Enderleinellidae, Hoplopleuridae, Linognathidae and Polyplacidae). Forty two of these species (95.5\%) have been associated with 61 species of rodents belonging to 4 families (Cricetidae, Heteromyidae, Muridae and Sciuridae), and 21 genera distributed in 28 states of the Mexican Republic (Sánchez-Montes, Guzmán-Cornejo, León-Paniagua, \& Rivas, 2013). As part of a project to describe the metazoan fauna associated with cricetid rodents from montane forests of Mexico, we determined the richness and abundance of sucking lice associated with cricetid rodents from forest in the mountains of Guerrero and Oaxaca, Mexico. For this purpose we identified the specimens morphologically and molecularly (using the cytochrome oxidase subunit I [COI] gene) and additionally, we calculated the prevalence and mean abundance for each lice species.

\section{Material and methods}

From April to December 2010, hosts were collected under permission FAUT-0170 issued by Semarnat, Mexico from 5 localities, 2 in Guerrero and 3 from Oaxaca, Mexico (Table 1). Rodents were captured using 4 transects of 40 Sherman traps (Romero-Almaraz, Sánchez-Hernández, GarcíaEstrada, \& Owen, 2007), and sacrificed in compliance with the

Table 1

Sampling sites of specimens collected in this study.

\begin{tabular}{|c|c|c|c|}
\hline State & Locality & Geographic reference & Collection date \\
\hline \multirow{5}{*}{ Guerrero } & Parque Estatal Cerro del Huizteco, Municipality & $18^{\circ} 36^{\prime} 08.17^{\prime \prime} \mathrm{N}$ & 30 July-4 August, 2010 \\
\hline & Taxco & $\begin{array}{l}99^{\circ} 36^{\prime} 30.63^{\prime \prime} \mathrm{W} \\
2,499 \mathrm{~m}\end{array}$ & \\
\hline & Puerto del Gallo, Municipality General Heliodoro & $17^{\circ} 28^{\prime} 48.46^{\prime \prime} \mathrm{N}$ & 06-12 December, 2010 \\
\hline & Castillo & $\begin{array}{l}100^{\circ} 10^{\prime} 35.79^{\prime \prime} \mathrm{W} \\
2,584 \mathrm{~m}\end{array}$ & \\
\hline & La Yerba Buena, Municipality Santa Catarina & $16^{\circ} 13^{\prime} 59.88^{\prime \prime} \mathrm{N}$ & 30 April-5 May, 2010 \\
\hline \multirow[t]{6}{*}{ Oaxaca } & Juquila & $\begin{array}{l}97^{\circ} 16^{\prime} 59.88^{\prime \prime} \mathrm{W} \\
1,710 \mathrm{~m}\end{array}$ & \\
\hline & $3 \mathrm{~km}$ southern Punto Ixtepeji, Municipality Ixtlán de & $17^{\circ} 12^{\prime} 06.37^{\prime \prime} \mathrm{N}$ & 22-25 November, 2010 \\
\hline & Juárez & $\begin{array}{l}96^{\circ} 35^{\prime} 28.21^{\prime \prime} \mathrm{W} \\
2,537 \mathrm{~m}\end{array}$ & \\
\hline & km 134.5 Highway 175 Oaxaca-Tuxtepec 21 km & $17^{\circ} 25^{\prime} 10.20^{\prime \prime} \mathrm{N}$ & 22-25 November, 2010 \\
\hline & north of Guelatao & $96^{\circ} 29^{\prime} 53.30^{\prime \prime} \mathrm{W}$ & \\
\hline & & $2,919 \mathrm{~m}$ & \\
\hline
\end{tabular}

guidelines of the American Society of Mammalogy for the Use of Wildlife Mammals in Research (Gannon \& Sikes, 2007). Lice were recovered from the external surface of hosts, and were fixed and preserved in vials with $96 \%$ ethanol. Likewise, each host was brushed on a sheet of white paper to extract additional lice adhering to the fur, and was posteriorly processed in the laboratory. For morphological determination sucking lice were mounted on slides using the modified techniques of Kim, Pratt, and Stojanovich (1986) and Wirth and Marston (1968). Specimens were identified using the specialized keys of Cook and Beer (1959), Ewing (1935), Kim et al. (1986), Pratt and Lane (1951), Stojanovich and Pratt (1961a, 1961b) and Stojanovich and Pratt (1965). Prevalence and mean abundance were calculated according with (Bush, Lafferty, \& Lotz, 1997). Additionally micrographs of specimens were taken using a Photomicroscope Olympus Provis AX70. Sucking lice were deposited in the collection of Laboratorio de Acarología, Facultad de Ciencias (LAFC), Universidad Nacional Autónoma de México.

DNA extraction was performed using the DNeasy Blood \& Tissue Kit (QIAGEN Ltd., UK). Amplification of a partial segment of $\approx 620$ of COI was done using primers Jerry $5^{\prime}$-CAACATTTATTTTGATTTTTTGG- $3^{\prime}$ and PatII $5^{\prime}$ TCCATTACATATAATCTGCCATATTAG-3' (Marsico et al., 2010).

The reaction mixture consisted of $2 \mu \mathrm{l}$ of primers $(10 \mu \mathrm{M}$, $1 \mu \mathrm{l}$ each), $0.4 \mu \mathrm{l}$ (1.25 units) of Taq DNA Axygen ${ }^{\circledR}, 2.0 \mu \mathrm{L}$ of $10 \times$ Promega reaction buffer, $2 \mu \mathrm{L}$ of $25 \mathrm{mM} \mathrm{MgCl}_{2}, 0.8 \mu \mathrm{L}$ of $10 \mathrm{mM}$ mix dNTPs, $12.3 \mu \mathrm{L}$ nuclease-free water and $5 \mathrm{ng}$ DNA in a final volume of $19.5 \mu \mathrm{L}$. PCR conditions were those used by Marsico et al. (2010). The PCR products were analyzed by electrophoresis on $1.5 \%$ agarose gels, using a $100 \mathrm{bp}$ and $1 \mathrm{~kb}$ molecular weight marker (nucleic acid markers, Axygen) in $1 \times$ TBE buffer.

Purified amplification products were submitted for sequencing to Unidad de Síntesis y Secuenciación de DNA (USSDNA), Instituto de Biotecnología and Laboratorio de Biología Molecular y de la Salud, Instituto de Biología, Universidad Nacional Autónoma de México. Sequences were compared with other sequences of sucking lice available in GenBank using the basic 
Table 2

Prevalence and mean abundance of sucking lice collected from rodents in 5 localities in the neotropical region of Mexico.

\begin{tabular}{|c|c|c|c|c|c|c|}
\hline Locality/host species & $n$ & HP & Sucking lice species & TSL & $\%$ & $A$ \\
\hline \multicolumn{7}{|l|}{ Guerrero } \\
\hline \multicolumn{7}{|l|}{ Parque Estatal Cerro del Huizteco } \\
\hline Habromys schmidly & 6 & 3 & H. reithrodontomydis & 12 & 50.0 & 2.0 \\
\hline \multicolumn{7}{|l|}{ Romo-Vázquez et al., 2005} \\
\hline Liomys pictus & 5 & 2 & F. microcephala & 15 & 40.0 & 3.0 \\
\hline \multicolumn{7}{|l|}{ Thomas, 1893} \\
\hline \multicolumn{7}{|l|}{ Puerto del Gallo } \\
\hline Megadontomys thomasi & 15 & 10 & H. emphereia & 66 & 66.7 & 4.4 \\
\hline \multicolumn{7}{|l|}{ Merriam, 1898} \\
\hline Neotoma mexicana & 2 & 2 & N. neotomae & 9 & 100.0 & 4.5 \\
\hline \multicolumn{7}{|l|}{ Baird 1855} \\
\hline Peromyscus beatae & 10 & 5 & P. auricularis & 7 & 50.0 & 0.7 \\
\hline \multicolumn{7}{|l|}{ Thomas, 1903} \\
\hline Peromyscus megalops & 15 & 9 & H. emphereia & 62 & 13.3 & 1.0 \\
\hline Merriam, 1898 & & 2 & P. auricularis & 15 & 60.0 & 4.1 \\
\hline Reithodontomys bakeri & 1 & 1 & H. reithrodontomydis & 3 & 100.0 & 3.0 \\
\hline \multicolumn{7}{|c|}{$\begin{array}{l}\text { Bradley, Mendez-Harclerode, Hamilton and Ceballos, } \\
2003\end{array}$} \\
\hline Reithrodontomys sumichrasti & 5 & 3 & H. reithrodontomydis & 5 & 60.0 & 1.0 \\
\hline \multicolumn{7}{|l|}{ Saussure, 1861} \\
\hline \multicolumn{7}{|l|}{ Oaxaca } \\
\hline \multicolumn{7}{|l|}{ La Yerba Buena } \\
\hline Peromyscus aztecus & 15 & 2 & H. ferrisi & 6 & 13.3 & 0.4 \\
\hline \multicolumn{7}{|l|}{ Saussure, 1860} \\
\hline Peromyscus melanurus & 35 & 4 & H. ferrisi & 19 & 11.4 & 0.5 \\
\hline \multicolumn{7}{|l|}{ Osgood, 1909} \\
\hline Reithrodontomys mexicanus & 1 & 1 & H. reithrodontomydis & 1 & 100.0 & 1.0 \\
\hline \multicolumn{7}{|l|}{ Saussure 1860} \\
\hline \multicolumn{7}{|l|}{$3 \mathrm{~km}$ al Sur del Punto Ixtepeji } \\
\hline Peromyscus beatae & 4 & 1 & P. auricularis & 3 & 25.0 & 0.8 \\
\hline Peromyscus megalops & 26 & 12 & H. emphereia & 133 & 46.2 & 5.1 \\
\hline \multicolumn{7}{|l|}{ Oaxaca-Tuxtepec } \\
\hline \multicolumn{7}{|l|}{ Km 134.5 de la Carretera 175} \\
\hline Peromyscus aztecus & 2 & 1 & H. emphereia & 2 & 50.0 & 1.0 \\
\hline Peromyscus beatae & 3 & 1 & P. auricularis & 2 & 33.3 & 0.7 \\
\hline Reithrodontomys mexicanus & 2 & 1 & H. reithrodontomydis & 26 & 50.0 & 13.0 \\
\hline
\end{tabular}

Host collected: HP, host parasitized; TSL, total of sucking lice; \%, prevalence; A, mean abundance.

local alignment search tool [BLAST] (Altschul, Gish, Miller, Myers, \& Lipman, 1990). The sequences obtained were submitted to GenBank.

Additionally to our sequences, we obtained another 25 from GenBank belonging to the families Hoplopleuridae and Polyplacidae, and 1 Ischnoceran (Columbicola columbae), which was used as an outgroup in accordance with the proposal of Light et al. (2010), with the following accession numbers: AF385003, AF545717, DQ324548, DQ324549, DQ324564, DQ324578, EU162163, EU375771, HM171425, HM171426, HM171427, HM171428, HM171429, HM171430, HM171431, HM171432, HM171433, HM171442, HM171443, HM171444, HM171445, HQ542195, HQ542196.

Sequences were edited and analyzed in Mega 5.1 software (Tamura, Peterson, Peterson, Stecher, Nei, \& Kumar, 2011), all were aligned using Clustal W (Thompson, Higgins, \& Gibson, 1994). Mega 5.1 was used to select the best nucleotide substitution model. A Neighbor-joining phylogenetic tree was generated using the Tamura 3 parameter distance model. Additionally, uncorrected pairwise ' $p$ ' divergences were calculated for comparative purposes.

\section{Results}

A total of 147 hosts pertaining to 10 species and 5 genera of Cricetidae (Habromys schmidly, Megadonthomys thomasi, Neotoma mexicana, Peromyscus aztecus, Peromyscus beatae, Peromyscus megalops, Peromyscus melanurus, Reithrodontomys bakeri, Reithrodontomys sumichrasti, Reithrodontomys mexicanus) and 1 Heteromyidae (Liomys pictus) were reviewed. These hosts were infested by 378 sucking lice $\left(189\right.$ \%, $106 \sigma^{7}$, 83 nymphs), distributed in 6 species belonging to 2 families (Hoplopleuridae and Polyplacidae) and 4 genera (Fahrenholzia, Hoplopleura, Neohaematopinus and Polyplax). The heteromids were included since they were collected during the collection of rodents in Cerro del Huizteco, Guerrero, and also because they were parasitized by sucking lice.

Rodent species distributed in 2 or more localities were infected by the same lice species, excepting $P$. aztecus which was parasitized by a different species in the sites where it was collected (Table 2). Almost all rodent species harbored only 1 species of sucking lice, excepting $P$. megalops, which was co-infested by $H$. emphereia and P. auricularis in Puerto 
A

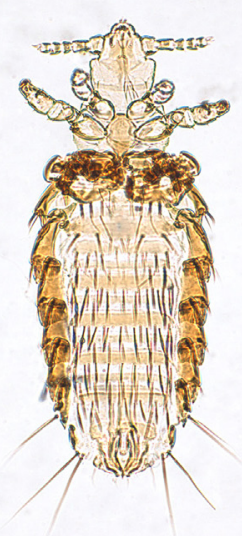

$200 \mu \mathrm{m}$
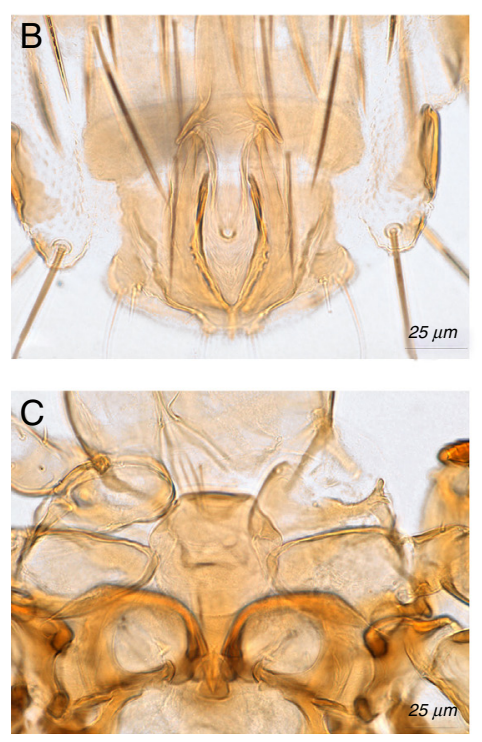

D
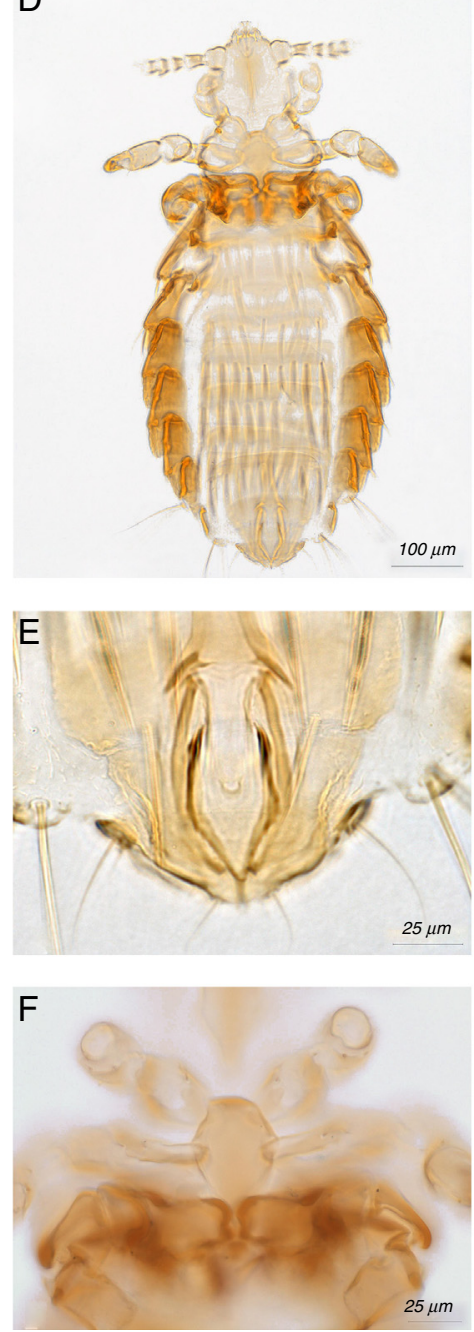
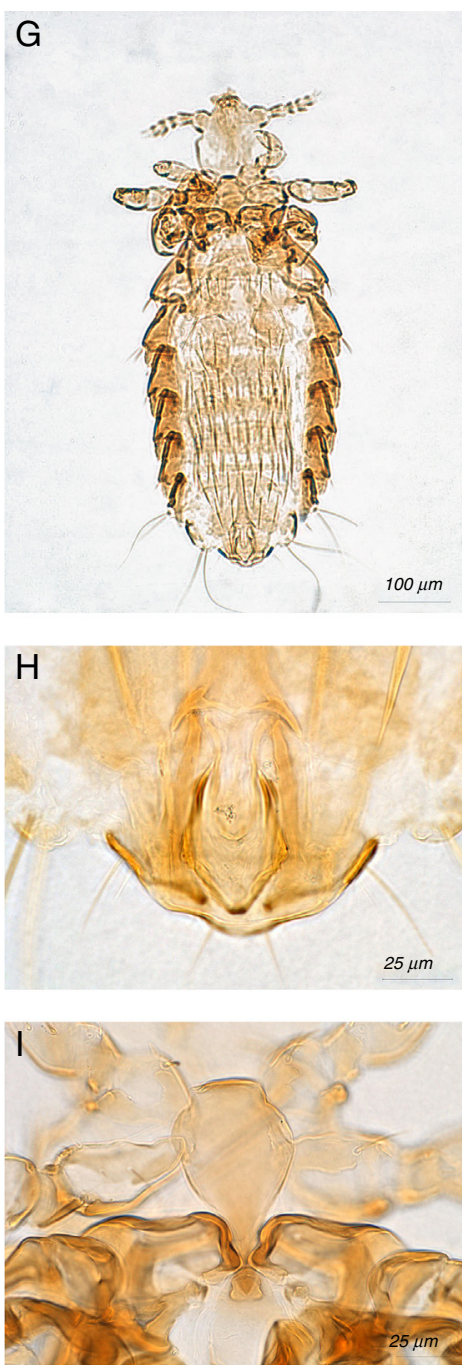

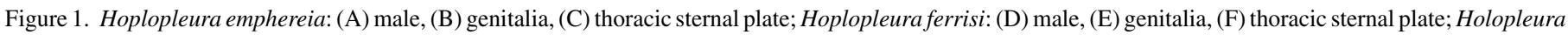
reithrodontomydis: $(\mathrm{G})$ male, $(\mathrm{H})$ genitalia, $(\mathrm{I})$ thoracic sternal plate.

del Gallo, Guerrero. Hoplopleura reithrodontomydis showed the highest geographic distribution, being found in 4 of the 5 sampled localities. These sucking lice were the most generalist species and were found in association with 4 cricetids species (H. schmidly, R. bakeri, R. mexicanus, and R. sumichrasti). On the other hand, $N$. neotoma and $F$. microcephala were found in only 1 host species at a single locality. The number of host species collected among localities varied from 1 to 6; the highest specific richness was recorded in Puerto del Gallo, Guerrero with 4 species of lice associated with 6 species of cricetids; in contrast, Parque Estatal Cerro del Huizteco exhibited the lowest species richness, as only 2 species were collected infesting 2 host species. Considering only populations of rodents represented by 10 or more specimens, prevalence ranged from 50 to $66.7 \%$, while mean abundance varies from 4.4 to 5.1 ; among these populations, the highest levels of prevalence and mean abundance were reached by $H$. emphereia in $M$. thomasi in Puerto del Gallo and P. megalops in $3 \mathrm{~km}$ southern Punto Ixtepeji, respectively (Table 2). Below, we present previous geographic distribution and the new records obtained in this study for each species of sucking lice recovered.

\section{Family Hoplopleuridae}

Hoplopleura emphereia Kim, 1965 (Fig. 1A-C)

\section{Material studied}

$4 \sigma^{7}, 7$, $3 \mathrm{~km}$ southern Punto Ixtepeji, Municipality de Ixtlán

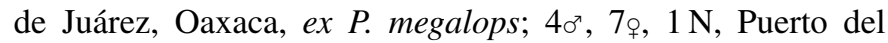
Gallo, Municipality General Heliodoro García, Guerrero, ex M. thomasi; 20 $\sigma^{7}, 6 \circ, 3$ N, Puerto del Gallo, Municipality General Heliodoro García, Guerrero, ex P. megalops.

\section{Distribution}

Guatemala, Mexico, Nicaragua and Panama (Castro \& González, 1997).

Hoplopleura ferrisi Cook \& Beer, 1959 (Fig. 1D-F) 


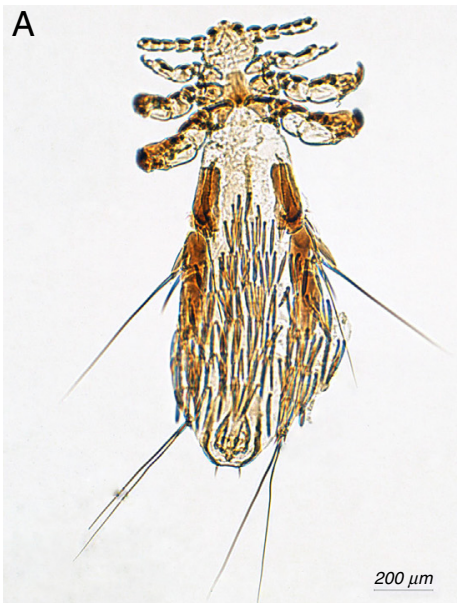

D

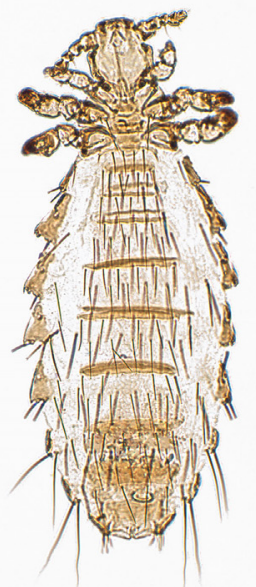

$200 \mu \mathrm{m}$
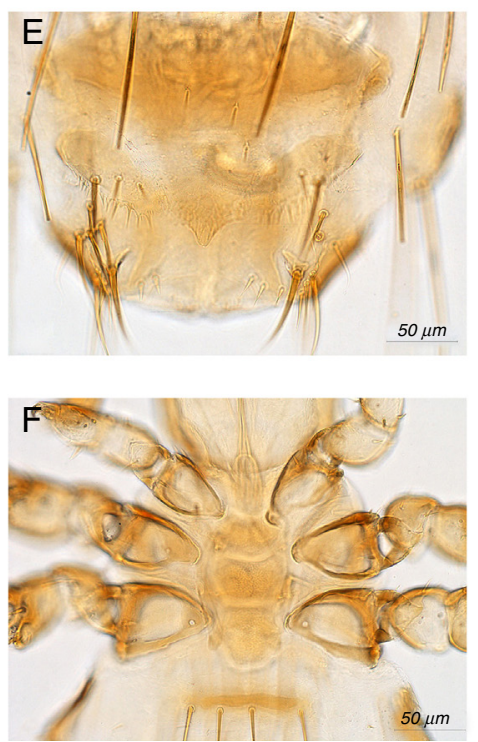

G

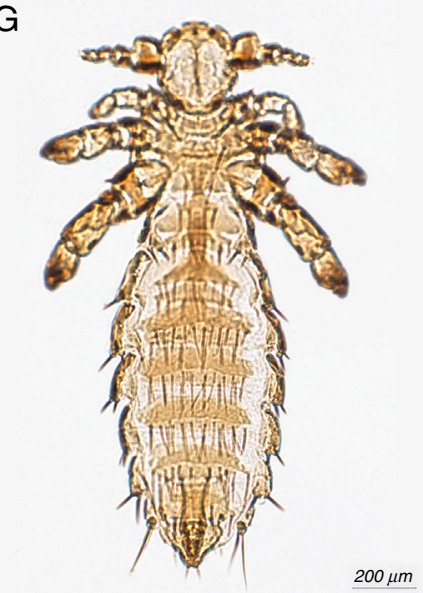

$200 \mu m$
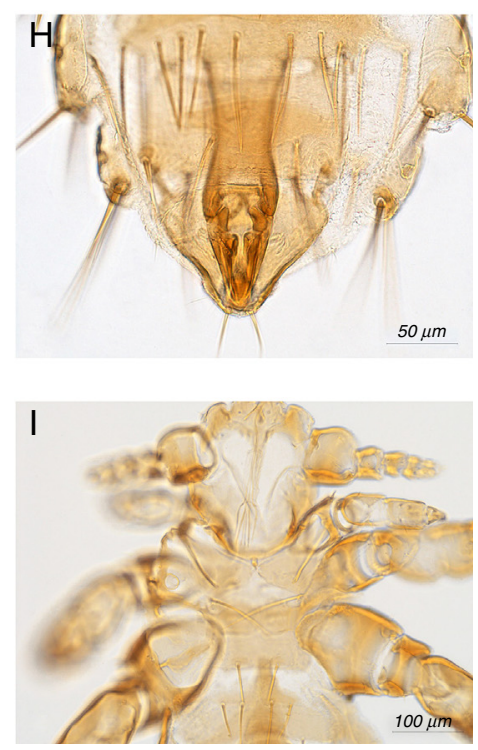

Figure 2. Fahrenholzia microcephala: (A) male, (B) genitalia, (C) thoracic sternal plate; Neohaematopinus neotomae: (D) female, (E) genitalia, (F) thoracic sternal plate; Polyplax auricularis: (G) male, (H) genitalia, (I) thoracic sternal plate.

\section{Material studied}

207, 4\%, La Yerba Buena, Municipality Santa Catarina

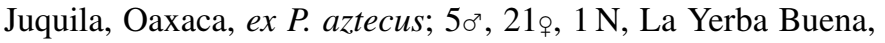
Municipality Santa Catarina Juquila, Oaxaca, ex P. melanurus. $2_{\rho}, \mathrm{Km} 134.5$ de la Carretera 175 Oaxaca-Tuxtepec a $21 \mathrm{Km}$ al Norte de Guelatao, Oaxaca, ex P. aztecus.

\section{Distribution}

Southeastern of United States (Arizona, Nuevo Mexico) to Mexico (Kim et al., 1986).

Hoplopleura reithrodontomydis Ferris, 1951 (Fig. 1G-I)

\section{Material studied}

$30^{\rtimes}, 3 \%$, Parque Estatal Cerro del Huizteco, Municipality Taxco, Guerrero, ex H. schmidly. 10`, La Yerba Buena, Municipality Santa Catarina Juquila, Oaxaca, ex R. mexicanus. 10 1 , $7 \mathrm{~N}, 3 \mathrm{~km}$ al sur del Punto Ixtepeji, Municipality Ixtlán de Juárez, Oaxaca, ex R. mexicanus. 1ơ, $1 \%, 1 \mathrm{~N}$, Puerto del
Gallo, Municipality General Heliodoro Castillo, Guerrero, ex R. sumichrasti.

\section{Distribution}

Southeastern of United States, Mexico to Central America (Kim et al., 1986).

\section{Family Polyplacidae}

Fahrenholzia microcephala Ferris, 1922 (Fig. 2A-C)

\section{Material studied}

$3 \sigma^{\circ}, 2 \circ, 2 \mathrm{~N}$, Parque Estatal Cerro del Huizteco, Municipality Taxco, Guerrero, ex L. pictus.

\section{Distribution}

South-eastern of United States to Mexico (Kim et al., 1986).

Neohaematopinus neotomae Ferris, 1942 (Fig. 2D-F) 
Table 3

Matrix of uncorrected pairwise ' $p$ ' distances.

\begin{tabular}{|c|c|c|c|c|c|}
\hline Sequence & $\begin{array}{l}\text { Fahrenholzia } \\
\text { microcephala }\end{array}$ & $\begin{array}{l}\text { Hoplopleura } \\
\text { emphereia }\end{array}$ & $\begin{array}{l}\text { Hoplopleura } \\
\text { reithrodontomydis }\end{array}$ & $\begin{array}{l}\text { Neohaematopinus } \\
\text { neotomae }\end{array}$ & $\begin{array}{l}\text { Polyplax } \\
\text { auricularis }\end{array}$ \\
\hline Neohaematopinus neotomae (HM171451.1) & 0.27 & 0.22 & 0.21 & 0.02 & 0.29 \\
\hline Neohaematopinus sciuropteri (HM171452.1) & 0.27 & 0.26 & 0.25 & 0.20 & 0.23 \\
\hline Hoplopleura arizonensis (HM171425.1) & 0.32 & 0.22 & 0.18 & 0.25 & 0.23 \\
\hline Hoplopleura erratica (HM171426.1) & 0.31 & 0.27 & 0.21 & 0.23 & 0.23 \\
\hline Hoplopleura ferrisi (HM171427.1) & 0.31 & 0.10 & 0.10 & 0.21 & 0.27 \\
\hline Hoplopleura ferrisi (HM171428.1) & 0.27 & 0.18 & 0.14 & 0.20 & 0.25 \\
\hline Hoplopleura hesperomydis (AF545717.1) & 0.29 & 0.19 & 0.18 & 0.19 & 0.24 \\
\hline Hoplopleura hesperomydis (HM171429.1) & 0.30 & 0.20 & 0.21 & 0.23 & 0.26 \\
\hline Hoplopleura hirsuta (HM171430.1) & 0.31 & 0.23 & 0.21 & 0.24 & 0.25 \\
\hline Hoplopleura onychomydis (HM171431.1) & 0.30 & 0.24 & 0.19 & 0.24 & 0.27 \\
\hline Hoplopleura quadridentata (EU375771.1) & 0.31 & 0.21 & 0.19 & 0.23 & 0.28 \\
\hline Hoplopleura reithrodontomydis (HM171432.1) & 0.29 & 0.15 & 0.04 & 0.21 & 0.27 \\
\hline Hoplopleura reithrodontomydis (HM171433.1) & 0.29 & 0.15 & 0.04 & 0.21 & 0.27 \\
\hline Fahrenholzia ehrlichi (HM171442.1) & 0.22 & 0.31 & 0.30 & 0.27 & 0.27 \\
\hline Fahrenholzia ehrlichi (HM171443.1) & 0.20 & 0.31 & 0.30 & 0.30 & 0.27 \\
\hline Fahrenholzia microcephala (DQ324564.1) & 0.04 & 0.32 & 0.29 & 0.26 & 0.31 \\
\hline Fahrenholzia texana (DQ324578.1) & 0.23 & 0.32 & 0.30 & 0.27 & 0.25 \\
\hline Fahrenholzia reducta (HM171444.1) & 0.25 & 0.27 & 0.30 & 0.23 & 0.26 \\
\hline Fahrenholzia zacatecae (HM171445.1) & 0.25 & 0.29 & 0.25 & 0.25 & 0.25 \\
\hline Polyplax auricularis (DQ324549.1) & 0.29 & 0.27 & 0.28 & 0.29 & 0.03 \\
\hline Polyplax borealis (DQ324548.1) & 0.25 & 0.27 & 0.26 & 0.22 & 0.23 \\
\hline Polyplax spinulosa (HQ542196.1) & 0.27 & 0.28 & 0.25 & 0.24 & 0.23 \\
\hline Polyplax spinulosa (HQ542195.1) & 0.27 & 0.28 & 0.25 & 0.24 & 0.23 \\
\hline Polyplax serrata (EU162163.1) & 0.27 & 0.30 & 0.27 & 0.28 & 0.23 \\
\hline Fahrenholzia microcephala & & 0.33 & 0.29 & 0.27 & 0.29 \\
\hline Hoplopleura emphereia & & & 0.12 & 0.22 & 0.27 \\
\hline Hoplopleura reithrodontomydis & & & & 0.21 & 0.27 \\
\hline Neohaematopinus neotomae & & & & & 0.28 \\
\hline
\end{tabular}

\section{Material studied}

$10^{\Im}$, 1\%, Puerto del Gallo, Municipality General Heliodoro Castillo, Guerrero, ex N. mexicana.

\section{Distribution}

South-eastern of United States to Mexico (Kim et al., 1986).

Polyplax auricularis Kellogg \& Ferris, 1915 (Fig. 2G-I)

\section{Material studied}

$30^{7}, 2 \circ, \mathrm{km} 134.5$ on Highway 175 Oaxaca-Tuxtepec, $21 \mathrm{~km}$ northern Guelatao, Oaxaca, ex P. beatae; 280", 46o $17 \mathrm{~N}, \mathrm{~km} 134.5$ on Highway 175 Oaxaca-Tuxtepec, $21 \mathrm{~km}$ northern Guelatao, Oaxaca, ex P. beatae; $10^{7}, 2 \propto$ Puerto del Gallo, Municipality General Heliodoro Castillo, Guerrero, ex P. beatae; $2 \sigma^{\rtimes}, 2 \wp, 2 \mathrm{~N}$ Puerto del Gallo, Municipality General Heliodoro Castillo, Guerrero, ex P. megalops.

\section{Distribution}

From Alaska to Southern United States, Mexico, Costa Rica and Venezuela (Kim et al., 1986).

\section{Molecular characterization}

DNA sequences of the COI were obtained for 5 of the 6 species analyzed, F. microcephala (GenBank accession number KT151124); H. emphereia (GenBank accession number KT151125), H. reithrodontomydis (GenBank accession number KT151126), N. neotomae (GenBank accession number KT151127) and $P$. auricularis (GenBank accession number KT151128). No DNA sequences were obtained for H. ferrisi.

The intraspecific uncorrected pairwise $p$-distances between COI sequences generated in this study and those obtained for GenBank ranged from $2 \%$ to $4 \%$ : N. neotomae (2\%), P. auricularis (3\%), and F. microcephala and $H$. reithrodontomydis (4\%); no sequence for pair comparison was available for H. emphereia on databases. On the other hand, the interspecific variation ranged from $10 \%$ (H. reithrodontomydis vs $H$. ferrisi) to $27 \%$ (H. emphereia vs H. erratica) in Hoplopleura; from $20 \%$ (F. ehrlichi vs F. microcephala) to $25 \%$ (F. microcephala vs F. zacatecae and F. reducta) in Fahrenzolzia; 23\% in Polyplax ( $P$. auricularis vs $P$. borealis, $P$. spinulosa and $P$. serrata); and $20 \%$ in Neohaematopinus (N. neotomae vs N. sciuropteri (Osborn, 1891)) (Table 3).

Four major groups can be recognized in the dendrogram constructed using the neighbor-joining method (Fig. 3). Each group contains species pertaining to the same genus (Fahrenholzia, Polyplax, Neohaematopinus, and Hoplopleura). The identity of 4 of the 5 lice species was confirmed by molecular analysis, since the sequences generated in this study joined with the respective sequence for each species obtained from GenBank, except for that of $H$. emphereia which was grouped with that of $H$. ferrisi (Fig. 3). 


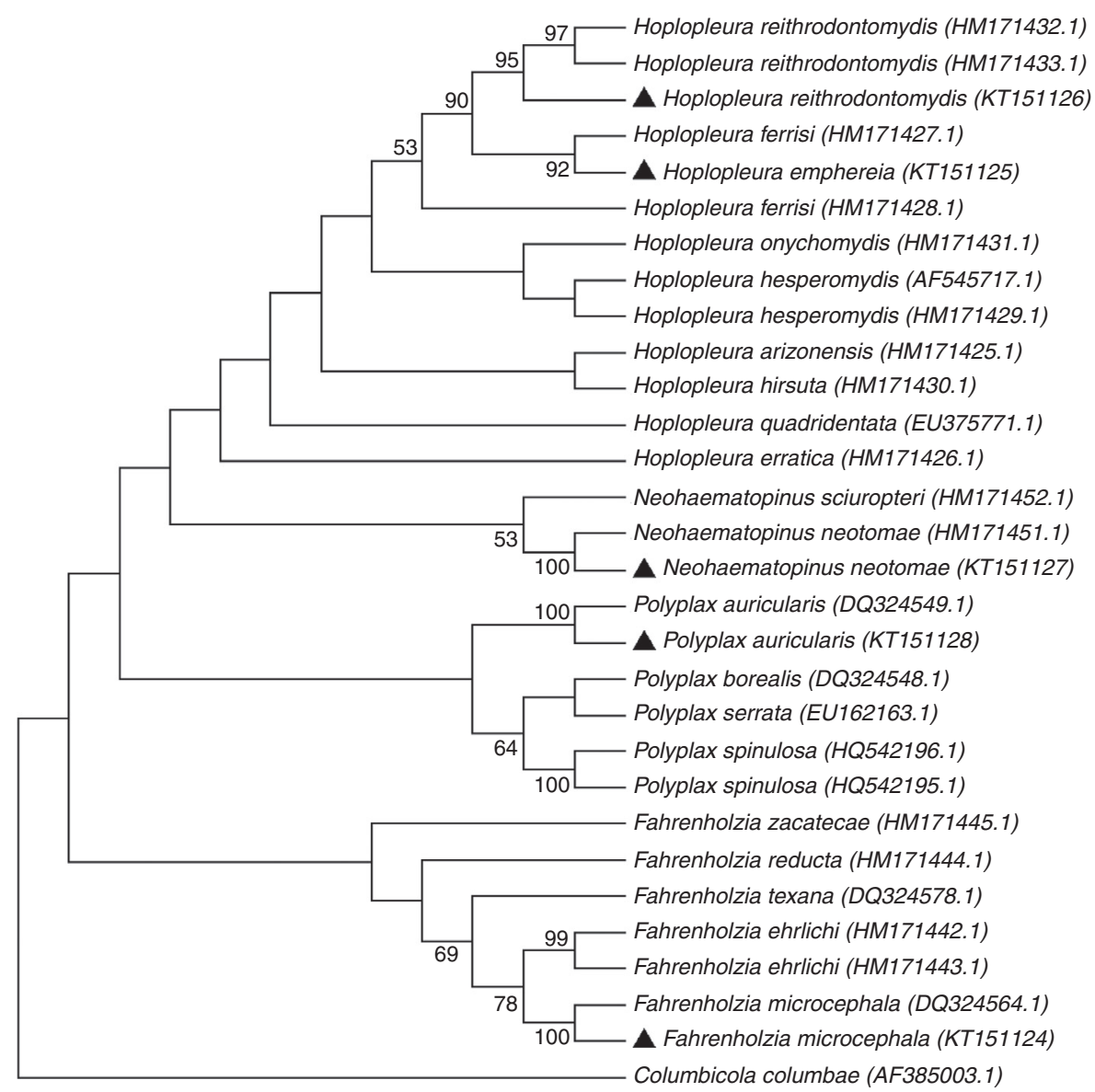

Figure 3. Neighbor-joining phylogenetic tree generated with partial sequences of the COI gene of sucking lice using Tamura 3 parameters distance model. Boostrap values are indicated in the nodes.

\section{Discussion}

As a result of this study, the geographic distribution of the 6 species recorded is increased since we present 13 new locality records. Nine of the 10 cricetid rodents sampled (H. schmidly, N. mexicana, P. aztecus, P. beatae, P. megalops (for P. auricularis), P. melanurus, $R$. bakeri, $R$. sumichrasti, $R$. mexicanus) represent new host records for their associated sucking lice species (Sánchez-Montes et al., 2013).

Among the recorded sucking lice, $H$. reithrodontomydis was the most widely distributed species. This species has been recorded infesting only arboricolous and semi-arboricolous rodents of the genus Reithrodontomys (Ceballos \& Oliva, 2005), which suggests a possible phenomenon of horizontal transmission between the arboreal host species. The finding of $H$. reithrodontomydis on $H$. schmidly is the first record for a host species other than from Reithrodontomys spp.; nonetheless, its presence on $H$. schmidly could be explained by its arboreal habits (Romo-Vázquez, León-Paniagua, \& Sánchez, 2005) co-existing with 2 Reithrodontomys microdon Merriam, 1901; however, the latter host species was not infested by sucking lice.

In accordance with Durden (2002), sucking lice diversity is correlated with host diversity, due to the high specificity exhibited by this arthropod group toward their mammal hosts. In this context, our results fit with this statement, since Puerto del Gallo the locality with the greatest rodent richness also exhibited the greatest sucking lice richness (6 species). In contrast, in Parque Estatal Cerro del Huizteco only 2 species of rodents and sucking lice were collected. Puerto del Gallo has been referred to as a well preserved area (Navarro, 1998); based on personal observations, we agree with Navarro (1998), while Cerro del Huizteco seems to be a more disturbed site. In this context, SaavedraMillán (2009), mentioned that Cerro del Huizteco is an area with low floral richness, due to the removal of herbaceous strata as a result of the introduction of infrastructure for ecotourism. This probably could explain the differential rodent richness in both localities.

Although most rodent species were parasitized by only 1 lice species, we recorded the co-infestation of $H$. emphereia and $P$. auricularis on P. megalops; this particular association had been previously recorded on Reithrodontomys creper Bangs 1902 in Panama (Johnson, 1972). The heterogeneous sample sizes obtained in our study preclude any conclusion about the factors involved in the infection levels recorded; however, variation on ecological parameters has been attributed to different factors such as, host sex, age, immune response, gregarious habits (Durden, 2002). In most sucking lice species infestation levels are less than 15 lice per parasitized host, being an extreme case H. emphereia associated with P. megalops in $3 \mathrm{Km}$ southern Punto Ixtepeji, whose range was 1-46 lice. 
Morphological identification of sucking lice is complex as most of the descriptions are based on a single specimen, lacking information about intraspecific variation, an aspect that should be analyzed. Three of the 6 species studied are well characterized morphologically; however, there is controversy about the validity of 3 other species (H. emphereia, H. ferrisi and $H$. reithrodontomydis) included in the Hoplepleura hesperomydis complex by Kim (1965). This author mentioned that $H$. emphereia shares morphological characters with $\mathrm{H}$. ferrisi; later, Johnson (1972) postulated that $H$. emphereia and $H$. reithrodontomydis could be the same species upon comparison of nymphal stages. In this work we identified the 3 species morphologically; $H$. reithrodontomydis differs of $H$. emphereia and $H$. ferrisi in the shape of abdominal paraterguite 8 , which presents a triangular shape, while in the other 2 species is rectangular. Likewise, H. emphereia males can be distinguished from $H$. ferrisi by the morphology of its thoracic sternal plate which have a posterior process abruptly pointed and paramers abruptly tapering posteriorly. In contrast, $H$. ferrisi males present thoracic sternal plate with posterior process gradually acute and paramers gradually tapering posteriorly (Johnson, 1972; Kim, 1965).

Intraspecific divergence values among DNA sequences of F. microcephala, $P$. auricularis, $N$. neotomae and $H$. reithrodontomydis (2-4\%) obtained in this study and those from GeneBank, allowed us to consider them as valid taxa, since some authors have cited higher ranges for different species, e.g., $13 \%$ within Hoplopleura tiptoni Johnson, 1972 and Hoplopleura rimae Johnson, 1972, 14\% for Hoplopleura aitkeni Johnson, 1972, and 18\% for Hoplopleura brasiliensis Werneck, 1932 (Smith, Light, \& Durden, 2008). For $H$. ferrisi no COI sequences were obtained and for $H$. emphereia no sequences for comparative purposes were available in GenBank.

On the other hand, the similarity between the COI sequence of $H$. emphereia from Mexico and 1 of the 2 sequences of H. ferrisi obtained from GenBank (associated to Peromyscus difficilis (Allen, 1891) from Puebla) showed a genetic divergence of $10 \%$; this value suggests the misidentification of 1 of the 2 specimens involved; however, this situation can only be solved through more sampling of specimens of both taxa (Fig. 3).

In spite of the amount of information generated during the 20th century, the inventory of the sucking lice in Mexico remains scarce and fragmentary. To date, $88 \%$ of the mammals distributed in Mexico have been neglected as hosts of this arthropod group. Particularly for rodents, completing the inventory of sucking lice is a major challenge, as these mammals constituted the main group of hosts. Only by increasing the sampling of this group of vertebrates in Mexico, through systematic studies, and avoiding partial analysis of a particular group of ectoparasites, this host-parasite association will be understood.

\section{Acknowledgments}

This research was supported by the grant PAPIIT IN225410 from Programa de Apoyo a Proyectos de Investigación e Innovación Tecnológica, DGAPA-UNAM. We thank Luis García Prieto who kindly reviewed our manuscript and provided a number of valuable comments; Ana Isabel Bieler Antolín for obtaining micrographs of specimens; Laura Del CastilloMartínez for slide-mounting few louse specimens; Laura Margarita Márquez Valdelamar for her assistance in sequencing PCR products. We also thank Griselda Montiel, Rosario Chavarría, Mirna Hernández, Diego Barrales, Luis Darcy, Christina Lynggaard, Ricardo Paredes, Héctor Olguín, Giovani Canchola, Mónica Rodríguez, Pablo Colunga, Tania Marines, Deborah Veranea and Jesús Lugo for field assistance.

\section{References}

Altschul, S. F., Gish, W., Miller, W., Myers, E. W., \& Lipman, D. J. (1990). Basic local alignment search tool. Journal of Molecular Biology, 215, 403-410.

Bush, A. O., Lafferty, K. D., \& Lotz, J. M. (1997). Parasitology meets ecology on its own terms. Journal of Parasitology, 83, 575-583.

Castro, D. C., \& González, A. (1997). Species of the genus Hoplopleura Enderlein, 1904 rodent parasites from the neotropical region. Papeis Avulsos De Zoologia, 40, 203-215.

Ceballos, G., \& Oliva, G. (2005). Los mamíferos silvestres de México. México D.F.: Conabio-Fondo de Cultura Económica.

Cook, E. F., \& Beer, J. R. (1959). The inmature stages of the genus Hoplopleura (Anoplura: Hoplopleuridae) in North America, with descriptions of two new species. Journal of Parasitology, 5, 405-416.

Durden, L. A. (2002). Lice. In G. R. Mullen, \& L. A. Durden (Eds.), Medical and veterinary entomology (pp. 45-63). San Diego, CA: Academic Press/Elsevier Science.

Durden, L. A., \& Musser, G. G. (1994). The sucking lice (Insecta: Anoplura) of the world: a taxonomic checklist with records of mammalian hosts and geographical distributions. Bulletin of the American Museum of Natural History, 218, 1-90.

Ewing, H. E. (1935). The taxonomy of the anopluran genera Polyplax and Eremophthirius, including the description of new species. Proceedings of the Biological Society of Washington, 48, 201-210.

Gannon, W. L., \& Sikes, R. S. (2007). Guidelines of the American Society of Mammalogists for the use of wild mammals in research. Journal of Mammalogy, 88, 809-823.

Johnson, P. T. (1972). On the rodent infesting Anoplura of Panama. Great Basin Naturalist, 32, 121-136.

Kim, K. C. (1965). A review of the Hoplopleura hesperomydis complex (Anoplura, Hoplopleuridae). Journal of Parasitology, 51, 871-887.

Kim, K. C., Pratt, H. D., \& Stojanovich, C. J. (1986). The sucking lice of North America: an illustrated manual for identification. Philadelphia/London: The Pennsylvania State University Press, University Park.

Light, J. E., Smith, V. S., Allen, J. M., Durden, L. A., \& Reed, D. I. (2010) Evolutionary history of mammalian sucking lice (Phthiraptera: Anoplura). Evolutionary Biology, 10, 292-317.

Marsico, T. D., Wallace, L. E., Ervin, G. N., Brooks, C. P., McClure, J. E., \& Welch, M. E. (2010). Geographic patterns of genetic diversity from the native range of Cactoblastis cactorum (Berg) support the documented history of invasion and multiple introductions for invasive populations. Biological Invasions, 2, 654-671

Navarro A.G. (1998). Distribución geográfica y ecológica de la avifauna del estado de Guerrero, México. Ph.D. Thesis. México, D.F.: Facultad de Ciencias, Universidad Nacional Autónoma de México.

Pratt, H. D., \& Lane, J. E. (1951). Hoplopleura oryzomidis new species, with notes on other United States species of Hoplopleura (Anoplura: Haematopinidae). Journal of Parasitology, 37, 141-146.

Romero-Almaraz, M. L., Sánchez-Hernández, C., García-Estrada, C., \& Owen, R. D. (2007). Mamíferos pequeños. Manual de técnicas de captura, preparación, preservación y estudio. México, D.F.: Las Prensas de Ciencias.

Romo-Vázquez, E., León-Paniagua, L., \& Sánchez, O. (2005). A new species of Habromys (Rodentia: Neotominae) from Mexico. Proceedings of the Biological Society of Washington, 118, 605-618.

Saavedra-Millán F. (2009). Estudio de la vegetación del Parque Estatal Francisco Torres Moreno, Cerro del Huixteco, Taxco, Guerrero, México. 
Bachelor Thesis. México, D.F.: Facultad de Ciencias. Universidad Nacional Autónoma de México

Sánchez-Montes, S., Guzmán-Cornejo, C., León-Paniagua, L., \& Rivas, G. (2013). A checklist of sucking lice (Insecta: Phthiraptera: Anoplura) associated with Mexican wild mammals, including geographical records and a host-parasite list. Zootaxa, 3722, 183-203.

Smith, V. S., Light, J. E., \& Durden, L. A. (2008). Rodent louse diversity, phylogeny, and cospeciation in the Manu Biosphere Reserve, Peru. Biological Journal of the Linnean Society, 95, 598-610.

Stojanovich, C. J., \& Pratt, H. (1961a). Key to the North American sucking lice in the genera Hoplopleura and Neohaematopinus with descriptions of two species (Anoplura: Hoplopleuridae). Journal of Parasitology, 47, 312-316.

Stojanovich, C. J., \& Pratt, H. (1961b). Fahrenholzia texana, new species, with a key to the United States species of Fahrenholzia (Anoplura: Hoplopleuridae). Annals of the Entomological Society of America, 54, 693-696.
Stojanovich, C. J., \& Pratt, H. (1965). Key to Anoplura of North America. Atlanta, GA, USA: Department of Health, Education and Welfare Public Health Service, Communicable Disease Center.

Tamura, K., Peterson, D., Peterson, N., Stecher, G., Nei, M., \& Kumar, S. (2011). MEGA5: molecular evolutionary genetics analysis using maximum likelihood, evolutionary distance, and maximum parsimony methods. Molecular Biology and Evolution, http://dx.doi.org/10.1093/molbev/ msr121

Thompson, J. D., Higgins, D., \& Gibson, T. J. (1994). CLUSTAL W: improving the sensitivity of progressive multiple sequence alignment through sequence weighting, position-specific gap penalties and weight matrix choice. Nucleic Acids Research, 22, 4673-4680.

Wirth, W. W., \& Marston, N. (1968). A method for mounting small insects on microscope slides in Canada balsam. Annals of Entomology Society of America, 61, 783-784 